ISSN 2078-6441. Вісник Львівського університету. Серія географічна. 2013. Випуск 41. С. 117-125. Visnyk of the Lviv University. Series Geography. 2013. Issue 41. P. 117-125.

631.417.2:631.417.2(282.247.1-192.2)

\author{
іт лій енис \\ ьвівський н ціон льний університет імені в н \\ вул. . орошенк, 41, 79000, м. ввів, кр їн
}

ро н лізов но результ ти досліджень вмісту гумусу ясно-сірих і сірих лісових грунтів смового обужжя. $\mathrm{x}$ р ктеризов но вміст гумусу в структурних грег т х грунтів різного сільськогоспод рського використ ння. 'ясов но, що зі зменшенням розміру грег тів вміст гумусу збільшується і грунти під лісом м ють ліпші пок зники вмісту гумусу.

лючові слов : сірі лісові грунти, ясно-сірі лісові грунти, гумус, грег ти, структур .

рунтотворний процес тісно пов'яз ний з н гром дженням і колообігом орг нічної речовини - одного з в жливих компонентів грунту. грунтовому перегної містяться і зберіг ються протягом трив лого ч су основні елементи живлення рослин. рг нічн речовин грунту є джерелом елементів живлення, що вивільняються в процесі мінер ліз ції гумусу. ерегнійні речовини інтенсивно вплив ють н структуроутворення i, отже, н фізичні й фізико-хімічні вл стивості грунту [21, с. 88].

рг нічн речовин слугує лімітуючим чинником, який визн ч є біопродуктивність екосистем: від іï скл ду і дин міки з леж ть водно-фізичні вл стивості, протиерозійн стійкість грунтів, поведінк з бруднюв чів, які н дходять у грунт [23].

рирод гумусу і його скл д відобр ж ють умови грунтоутворення і ті глибинні зміни, які відбув ються в грунті вн слідок впливу чинників грунтоутворення [19, с. 86].

умусові речовини є основним, н й ктивнішим гентом формув ння грунтових профілів [20, с. 3]. оняття “гумусовий профіль” відобр ж є розподіл гумусу в усій грунтовій товщі [12]. ерг човою, гумусовий профіль - це комбін ція, послідовність однорідних зон з певним поєдн нням і порівняно одн ковим ступенем інтенсивності елемент рних гумусоутворюв льних процесів. умусовий профіль сірих лісових грунтів . ерг чов з числил до окремого типу профілів, які м ють дуже скл дне і мінливе поєдн ння зон у меж х профілю. ей тип профілів потребує н йбільшої дет ліз ції т дод ткових експеримент льних досліджень [10, с. 43-45].

н літичній х р ктеристиці гумусу в різних тип х грунтів н д в ли в жливого зн чення ще з довго до виникнення генетичного грунтозн вств, сформов ного . окуч євим, . остичевим, . ибірцевим.

ивчення природи гумусу, його скл ду і вл стивостей н суч сному ет пі розвитку грунтозн вчої н уки пов'яз ні з імен ми . юрін, . ононової; . оном рьової, . ільямс . . н , . лекс ндрової, . рлов , . лотникової, . рішиної т інших. ит нню дослідження гумусного ст ну грунтів ісостепу кр їни присвячені пр ці . ндрущенк, . ерн ндер, - одлін, · в ші, · ктіонов , В. ухи т інших [21, с. 88]. ьогодні вивченням гумусу як в жливого екологічного чинник 3 -

енис ., 2013 
йм ється . рп чевський. території смового обужжя гумусовий ст н грунтів досліджує . ідв льн .

собливу ув гу приділяють вивченню зміни гумусового ст ну грунтів ун слідок інтенсивного нтропогенного впливу. відміну від мінер льної, орг нічн ч стин грунту з зн є зн чних змін у р зі сільськогоспод рського освоєння у кількісному т якісному спект х. тупінь вир женості зміни з лежить від термінів вирубув ння лісів т історії освоєння грунтів. оведінк гумусу різн в грунт х, які постійно обробляють після зведення лісу, і в тих, що трив лий ч с були покриті лучно-степовою рослинністю [4, с. 90].

ормув ння гумусового профілю визн чене не стільки з п с ми мертвої орг нічної м си, скільки умов ми гуміфік ції продуктів її розкл д ння т інтенсивністю прижиттєвих кореневих виділень, що безпосередньо пов'яз но з гідротермічним режимом грунтів. йліпші умови для гуміфік ції продуктів розкл дення збіг ються з оптим льним ступенем вологості грунту, який х р ктерний для р йонів з гідротермічним коефіцієнтом приблизно 1,0 [21, с. 89].

к і орг нічн речовин, грег тний ст н грунтів відігр є в жливу екологічну роль у житті і рослин, і тв рин. Звич й, природні грунти добре грегов ні. ослідження з свідчують, що одн із головних вл стивостей, які відрізняють грунт від грунтотворної породи, - це н явність гумусу і структури: новоутворення й грег ти [11, с. 43].

ількісний і якісний ст н гумусу вплив ють н оструктуреність грунтів. ост тня кількість і його гум тність сприяють утворенню т збереженню зернистої й грудкув то-зернистої структури і н д ють їй т кої в жливої х р ктеристики, як водотривкість і міцність.

труктурний ст н грунтів, тип грег тів з великою ймовірністю свідчить про х $\mathrm{p}$ ктер використ ння грунтів. сто с ме структурні окремості д ють змогу відрізнити грунти, які з генетичною природою близькі один до одного (чорнозем вилугув ний і темно-сірі опідзолені лісові грунти) тощо [11, с. 43].

ст нніми десятиліттями інтерес до проблеми структури грунтів знижується. ісля публік цій . едройц (1926), . околовського $(1933,1971)$, . нтіпов р т єв (1948), . ершинін (1959), . чинського (1963), . н (1969), з кордоном ж. ртін т ін. (1955), . енін т ін. (1958), . pic т ін. (1966) грунтовних досліджень в г лузі генези і вл стивостей структури грунтів у широких м сшт 6 х не проводили. другій половині ХХ ст. основну ув гу приділяли вивченню щільності будови й оцінці фізичного ст ну грунтів. огляду н це зг д ємо критичне з ув ження . ояренк (1963), який відд в в перев гу вивченню структури і диференці льної пористості порівняно зі щільністю будови [13, с. 7].

якою б в жливою не бул щільність будови, структур є фунд мент льною х р ктеристикою грунтів, бо від неї з леж ть екологічні і продуктивні функції, пр ктично всі режими, і н віть щільність будови є н слідком речовинного т якісного скл ду структури і щільності її будови в тілі грунту. ивченням структури грунтів у дин мічному розрізі присвячені пр ці . еён , . рофімов, . едведєв, . озняк т ін.

. ільямс пис в: “ ксим льного вир знення чинники родючості - вод і поживні речовини - досяг ють тільки в добре оструктуреному грунті. труктурний грунт - це той культурний фон землеробств, н який н кл д ються всі інші гротехнічні з ходи рослинництв " [8].

труктурн ч сточк : грег т скл д ється з первинних ч сточок (мех нічних елементів), бо мікро грег тів, з'єдн них між собою з вдяки ко гуляції колоїдів, склеюв н- 
ня, злип ння. і збільшенням грег ту зв'язок між окремими його ч сточк ми посл блюється і, як н слідок, зменшуються зв'язність і міцність. в'язність грунту з лежить від кількості мулистих і, особливо, колоїдних ч сточок. іцність зумовлен цемент цією мех нічних елементів свіжоос дженою орг нічною речовиною. . н сенко, вивч ючи структурно- грег тний ст н чорноземів, дослідив нег тивний вплив розорюв ння і з ліснення н вміст грономічно цінних грег тів [17].

грономічне зн чення структури грунту поляг є в тому, що вон 3 побіг є н дмірному ущільненню грунту, несприятливому для більшості рослин. руйнув нні й утворенні структури орних грунтів зн чну роль відігр є мех нічний обробіток, процеси мінер ліз ції т н копичення орг нічних речовин, с мі культурні рослини і грунтові мікроорг нізми, добрив , т кож сезонне перезволоження і промочув ння грунтів [7].

н ліз змін структурно- грег тного скл ду грунтів у р зі виведення їх із сільськогоспод рського використ ння виявив позитивні зміни в структурі грунтів з умов 3 лишення в перелозі, т кож з'ясов но, що під лісовою рослинністю відбув ється з г льне збільшення грономічно цінних грег тів і деяке збільшення ч сточок <0,25 мм [6].

уттєву роль у структуроутворенні відігр ють с ме біологічні генти, передусім, кореневі системи перев жно тр в'янистих рослин. орені пронизують грунт, розділяючи грунтову м су в одних місцях і стиск ючи їі в інших, лок льно висушують грунт і виділяють у місця конт кту орг нічну речовину. оширюючись в ед фотопі в різном нітних н прям х, коріння н д ють грег т м грудкув тої бо зернистої форми; проник ючи в мікро грег ти, вони зв'язують їх і підвищують мех нічну міцність т водотривкість [1].

пр цях . оронін дет льно сх р ктеризов но структурно-функціон льні вл стивості різних типів грунтів. ході дослідження розподілу гумусу в структурних грег т х він виявив, що суттєвий вплив н утворення мех нічно стійких і водостійких грег тів м є гумусов речовин й інші орг нічні сполуки, одн к прямої з лежності між розмір ми грег тів, кількістю і якістю гумусу в них зн йти не вд лося, н явні з цього пит ння д ні доволі неоднозн чні [9].

дні вчені $[5,14,15,26]$ з зн ч ють, що водотривкі м кро грег ти містять більше як 3 г льного вуглецю, т к і вуглецю “гумінів” т гумусових кислот порівняно з мікрогрег т ми, інші $[16,24]$ вв ж ють, що зі зменшенням розміру грег тів кількість гумусу в них і вміст міцнозв'яз них орг нічних речовин збільшув л сь, в сл бкозв'яз них - зменшув л сь. д ними деяких дослідників $[27,28]$, вміст гумусу у фр кціях грег тів >1 мм більш-менш однорідний, у фр кціях <1 мм з фіксов но зміну в його вмісті з лежно від зміни розміру фр кції. Г льн тенденція цих змін зводиться до того, що після деякого м ксимуму у вмісті орг нічних речовин, який прип д $€$ н фр кцію грег тів певного і х р ктерного для кожного типу грунтів розміру, фіксують його зниження до певного мінімуму, приуроченого до фр кцій мікро грег тів, т кож вл стивих кожному типу грунтів [9]. ивчення вмісту орг нічної речовини в мікро- і м кро грег т х з свідчують, що вміст гумусу в грег т х >1 мм є більш-менш однорідним [9].

ідсутність яких-небудь 3 кономірностей зміни в гр нулометричному скл ді, вмісті гумусу, ємності вбир ння, ефективній питомій поверхні м кро грег тів з лежно від їхніх розмірів дост тньо переконливо доводить, що вони утворюються вн слідок розділення неоднорідної до деякого ступеня грунтової м си н м крофр гменти в процесі перемінного ऑї висушув ння і зволоження [9]. 
процесі дослідження сірих лісових грунтів смового обужжя з кл дено три мод льні ділянки н уликівському, мереківському і лехівському п см х. порні розрізи з кл ли в лісі т н ріллі.

езульт ти досліджень з свідчили, що грунти під лісовою форм цією м ють більший вміст гумусу. йбільший вміст гумусу х р ктерний для ясно-сірих лісових грунтів уликівського п см . гумусово-елюві льному горизонті його вміст ст новить 2,54-1,21\%. нижній ч стині гумусово-елюві льного горизонту простежено різке зменшення вмісту гумусу до 1,21\%. низ по профілю вміст гумусу зменшується і в елюві льному сл бкогумусов ному горизонті ст новить $0,98 \%$, в ілюві льному сл бкоелювійов ному сл бкогумусов ному - 0,72\%. ріллі вміст гумусу є зн чно меншим. ксим льне зн чення вмісту гумусу з фіксов но у верхньому десятис нтиметровому ш рі $-1,90 \%$, в нижній ч стині орного горизонту $-1,64 \%$. ілюві льноелюві льному сл бкогумусов ному вміст гумусу ст новить $0,95 \%$, в ілюві льному сл бкоелювійов ному - 0,54\%. гр фіків б чимо, що н ріллі потужність прогумусов ної товщі $є$ більшою. е зумовлено ор нкою і перемішув нням гумусовоелюві льного ш ру (див. рисунок).

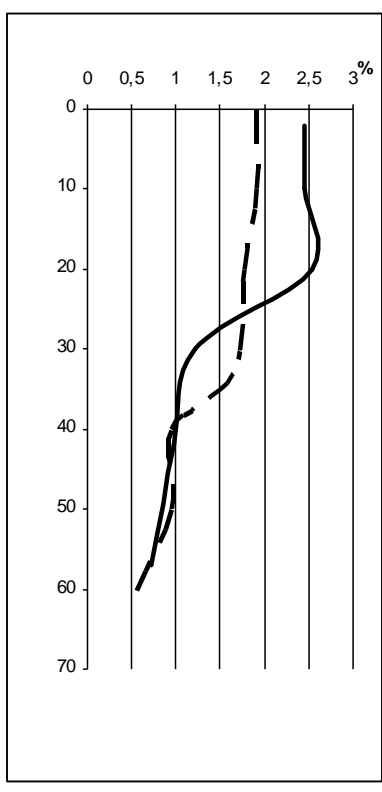

$I$

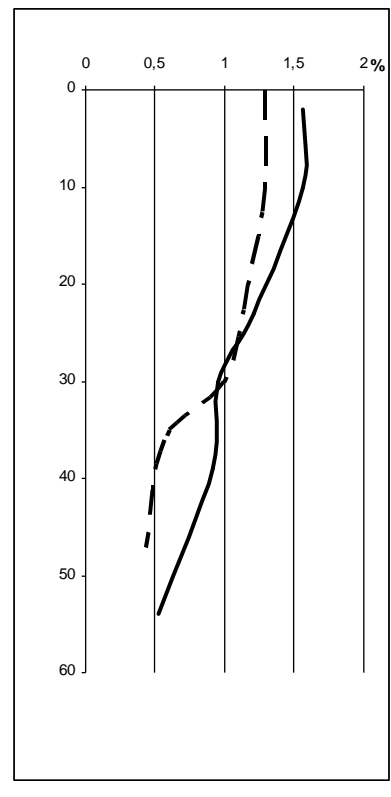

II

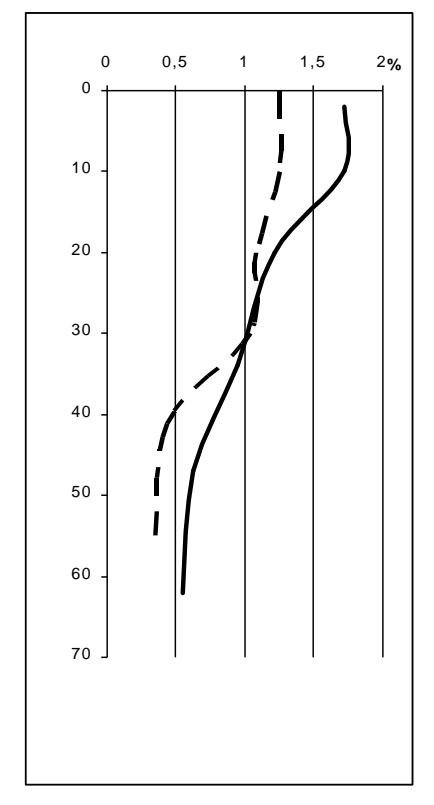

III

$$
-1 \quad--2
$$

міст гумусу сірих лісових грунтів смового обужжя:

$I$ - ясно-сірі лісові грунти уликівського п см ; II - сірі лісові грунти лехівського п см ; III-ясно-сірі лісові грунти мереківського п см . 1 -ліс; 2 -рілля.

iрi лісові грунти лехівського п см м ють дуже низький вміст гумусу. прикл д, у грунт х під лісом м ксим льний вміст у верхньому десятис нтиметровому ш рі ст новить $1,56 \%$, в нижній ч стині - 1,21, в ілюві льному сл бкогумусов ному 0,95-0,91, в ілюві льному сл бкоелювійов ному - 0,52\%. ріллі вміст гумусу є ще 
меншим і в орному горизонті ст новить $1,29-0,89 \%$, у підорному - 0,56, в ілюві льному сл бкогумусов ному - 0,43\%. грунті під ріллею гумусовоелюві льний горизонт однорідніший з вмістом гумусу і потужніший, що зумовлено трив лим обробітком.

ясно-сірих лісових грунт х мереківського п см т кож дуже низький вміст гумусу. ід лісовою форм цією вміст гумусу в гумусово-елюві льному горизонті ст новить $1,72-0,95 \%$, в елюві льно-гумусовому - 0,62 \%, в ілюві льно-елюві льному $0,55 \%$. рунти під ріллею м ють менший вміст гумусу, проте в нижній ч стині гумусово-елюві льного горизонту вміст гумусу н ріллі є вищим, ніж у грунт х під лісом, i ст новить 1,25-1,03\%, в елюві льно-гумусов ному - 0,43, в ілюві льно-елюві льному - 0,34 \% (див. т блицю, рисунок).

ході вивчення вл стивостей структурних грег тів грунтів досліджено вміст гумусу методом юрін в модифік ції ікітін в грег т х розміром >10, 10-7, 7-5, 5-3, 3-2, 2-1, 1-0,5 мм.

сно-сірі лісові грунти під лісом у меж х уликівського п см (розріз 1) м ють у гумусово-елюві льному горизонті н йменший вміст гумусу в грег т х 10-7 і 5-3 мм2,11 і 2,05\%, н йбільший вміст є у фр кції 1,0-0,5 мм - 2,50\%. ілюві льному сл бкоелювійов ному сл бкогумусов ному горизонті м ксим льне зн чення гумусу з фіксов но у фр кціях 2-1 і 1,0-0,5 мм і ст новить 0,80\% (див. т блицю). ясно-сірих лісових грунт х ріллі у верхньому гумусово-елюві льному горизонті з лежно від розміру грег тів вміст гумусу є різним. грег т х розміром 1,0-0,5 мм його вміст ст новить 2,27\%, зі збільшенням розміру грег тів зменшується до $1,61 \%$ в грег т х 10-7 мм. підорному ілюві льно-елюві льному сл бкогумусов ному горизонті вміст гумусу зменшується. і зменшенням розміру грег тів вміст гумусу зрост є й досяг є м ксим льного зн чення в грег т х розміром 2-1 т 1-0,5 мм і ст новить 1,29-1,22\%, мінім льне зн чення 3 фіксов не в грег т х >10, 10-7 мм - 1,0-0,95\%. ксим льний вміст гумусу в ілюві льно-елюві льному горизонті простежується в грег т х 1-0,5 мм і ст новить 0,67\%, мінім льне є в грег т х розміром 10-7 мм-0,40\% (див. т блицю).

ясно-сірих лісових грунт х мереківського п см під лісом (розріз 6) н йвищі поК зники вмісту гумусу є в грег т х розміром 1,0-0,5 мм-2,12\%, н йнижчі в грег T $\mathrm{x}$ розміром >10 мм (див. т блицю). і зменшенням розмірів грег тів вміст гумусу зрост є й досяг є м ксим льного зн чення в грег т х розміром 2-1 т 1,0-0,5 мм і ст новить в гумусово-елюві льному 1,12-1,23\%, в елюві льно-гумусовому 0,99, в ілюві льно-елюві льному - 0,71\%. інім льне зн чення вмісту гумусу виявлене в н йбільших грег т х розміром >10 мм, i, відповідно, ст новить у гумусовоелюві льному 1,61-0,87 \%, в елюві льно-гумусовому $0,48, \quad$ в ілюві льноелюві льному $0,40 \%$. ід ріллею в ясно-сірому лісовому грунті (розріз 5) у виділених горизонт х м ксим льні зн чення вмісту гумусу є в грег т х 1-0,5 мм, мінім льні в грег т х >10 мм. ідповідно, м ксим льні пок зники вмісту гумусу в орному горизонті ст новлять 1,42-1,20\%, в елюві льно-гумусовому - 0,63, в ілюві льноелюві льному - 0,47\%. інім льний вміст гумусу в грег т х розміром >10 мм в орному горизонті ст новить $1,11-0,95 \%$, в елюві льно-гумусовому - 0,39, в ілюві льноелюві льному - 0,30 \% (див. т блицю).

сірих лісових грунт х лехівського п см м ксим льний вміст гумусу з фіксов но в грег т х розміром 2-1 т 1,0-0,5 мм, він ст новить у гумусово-елюві льному $2,18-1,40$, в ілюві льному сл бкогумусов ному 1,06-1,01, в ілюві льному сл бкоелювійов ному $-0,72 \%$. інім льний вміст гумусу у фр кціях $>10$ мм ст новить у гумусово-елюві льному 1,53-1,11\%, в ілюві льному сл бкогумусов ному 0,75-0,73, в ілю- 
ві льному сл бкоелювійов ному 0,36 \%. ріллі (розріз 3) в гумусово-елюві льному горизонті м ксим льне зн чення вмісту гумусу в грег т х 2-1 т 1,0-0,5 мм в орному горизонті ст новить 1,40-1,14\%, у підорному - 0,71, в ілюві льному сл бкогумусов ному - 0,62\%. інім льні зн чення - в грег т х >10 мм т 10-7 мм і ст новить $1,19-0,88 \%$, у підорному в цих грег т х зменшується до $0,50 \%$, в ілюві льному сл бкогумусов ному ст новить $0,40 \%$ (див. т блицю).

міст гумусу у фр кціях грег тів сірих лісових грунтів смового обужжя

\begin{tabular}{|c|c|c|c|c|c|c|c|c|c|}
\hline \multirow{2}{*}{$\begin{array}{r}\text { енетичні } \\
\text { горизонти }\end{array}$} & \multirow{2}{*}{$\begin{array}{c}\text { либин } \\
\text { зр зк , см }\end{array}$} & \multirow{2}{*}{$\begin{array}{l}\text { горизонті } \\
\text { з г лом, \% }\end{array}$} & \multicolumn{7}{|c|}{ озмір грег тів, мм / вміст гумусу, \% } \\
\hline & & & $>10$ & $10-7$ & $7-5$ & $5-3$ & $3-2$ & $2-1$ & $1,0-0,5$ \\
\hline \multicolumn{10}{|c|}{ озріз 1. сно-сірі лісові (ліс) } \\
\hline $\mathrm{HE}$ & $2-10$ & 2,46 & 2,13 & 2,09 & 2,24 & 2,11 & 2,18 & 2,46 & 2,50 \\
\hline $\mathrm{HE}$ & $10-20$ & 2,54 & 2,14 & 2,20 & 2,26 & 2,31 & 2,28 & 2,52 & 2,49 \\
\hline $\mathrm{HE}$ & $20-29$ & 1,21 & 1,08 & 0,91 & 0,99 & 1,05 & 1,17 & 1,18 & 1,26 \\
\hline Eh & $32-42$ & 0,98 & 0,76 & 0,88 & 0,81 & 0,99 & 1,09 & 1,11 & 1,10 \\
\hline Ieh & $47-57$ & 0,72 & 0,66 & 0,69 & 0,69 & 0,69 & 0,71 & 0,80 & 0,80 \\
\hline \multicolumn{10}{|c|}{ озріз 2. сно-сірі лісові (рілля) } \\
\hline $\mathrm{H}$ op & $0-10$ & 1,90 & 1,61 & 1,51 & 1,72 & 1,96 & 1,90 & 2,12 & 2,27 \\
\hline HEop & $10-20$ & 1,76 & 1,23 & 1,36 & 1,44 & 1,51 & 1,91 & 1,87 & 1,94 \\
\hline HEop & $20-33$ & 1,64 & 1,26 & 1,32 & 1,33 & 1,47 & 1,58 & 1,66 & 1,71 \\
\hline IEh & $33-40$ & 0,95 & 1,08 & 1,00 & 1,08 & 1,21 & 1,20 & 1,29 & 1,25 \\
\hline IEh & $40-50$ & 0,95 & 0,95 & 1,00 & 1,00 & 0,99 & 1,08 & 1,17 & 1,22 \\
\hline Ie & $50-60$ & 0,54 & 0,43 & 0,40 & 0,56 & 0,60 & 0,59 & 0,57 & 0,67 \\
\hline \multicolumn{10}{|c|}{ озріз 4. ірі лісові (ліс) } \\
\hline $\mathrm{HE}$ & $2-10$ & 1,56 & 1,53 & 1,52 & 1,58 & 1,61 & 1,66 & 1,81 & 2,18 \\
\hline $\mathrm{HE}$ & $10-23$ & 1,21 & 1,11 & 1,13 & 1,15 & 1,19 & 1,20 & 1,31 & 1,40 \\
\hline Ih & $23-30$ & 0,95 & 0,75 & 0,80 & 0,88 & 0,89 & 0,93 & 0,96 & 1,06 \\
\hline Ih & $30-39$ & 0,91 & 0,73 & 0,78 & 0,80 & 0,79 & 0,90 & 0,98 & 1,01 \\
\hline $\mathrm{Ie}$ & $44-54$ & 0,52 & 0,36 & 0,40 & 0,46 & 0,50 & 0,53 & 0,60 & 0,72 \\
\hline \multicolumn{10}{|c|}{ озріз 3. ірі лісові (рілля) } \\
\hline Heop & $0-10$ & 1,29 & 1,21 & 1,19 & 1,27 & 1,42 & 1,38 & 1,40 & 1,40 \\
\hline Heop & $10-20$ & 1,16 & 1,01 & 1,09 & 1,13 & 1,14 & 1,10 & 1,18 & 1,23 \\
\hline Heop & $20-30$ & 0,99 & 0,88 & 0,96 & 0,90 & 0,89 & 1,00 & 1,08 & 1,14 \\
\hline Неп/ор & $31-36$ & 0,56 & 0,50 & 0,52 & 0,56 & 0,60 & 0,57 & 0,66 & 0,71 \\
\hline Ih & $37-47$ & 0,43 & 0,52 & 0,40 & 0,48 & 0,56 & 0,60 & 0,62 & 0,60 \\
\hline \multicolumn{10}{|c|}{ озріз 6. сно-сірі лісові (ліс) } \\
\hline $\mathrm{H}$ & $2-10$ & 1,72 & 1,61 & 1,69 & 1,70 & 1,77 & 1,87 & 1,99 & 2,12 \\
\hline $\mathrm{HE}$ & $10-20$ & 1,21 & 1,12 & 1,18 & 1,20 & 1,27 & 1,38 & 1,41 & 1,53 \\
\hline $\mathrm{HE}$ & $20-34$ & 0,95 & 0,87 & 0,90 & 0,93 & 1,00 & 1,09 & 1,13 & 1,23 \\
\hline $\mathrm{EH}$ & $37-47$ & 0,62 & 0,48 & 0,56 & 0,58 & 0,62 & 0,86 & 0,90 & 0,99 \\
\hline IE & $52-62$ & 0,55 & 0,40 & 0,55 & 0,54 & 0,60 & 0,61 & 0,70 & 0,71 \\
\hline \multicolumn{10}{|c|}{ озріз 5. сно-сірі лісові (ліс) } \\
\hline HEop & $0-10$ & 1,25 & 1,11 & 1,20 & 1,22 & 1,30 & 1,29 & 1,40 & 1,42 \\
\hline HEop & $10-20$ & 1,08 & 0,99 & 1,08 & 1,09 & 1,12 & 1,19 & 1,20 & 1,29 \\
\hline HEop & $20-30$ & 1,03 & 0,95 & 1,00 & 0,99 & 0,97 & 1,17 & 1,16 & 1,20 \\
\hline $\mathrm{EH}$ & $31-41$ & 0,43 & 0,39 & 0,40 & 0,40 & 0,42 & 0,47 & 0,50 & 0,63 \\
\hline IE & $45-55$ & 0,34 & 0,30 & 0,33 & 0,39 & 0,43 & 0,43 & 0,47 & 0,47 \\
\hline
\end{tabular}


тже, н ліз л бор торних досліджень з свідчив, що вміст гумусу в грунт х під лісовим біоценозом вищий, н ріллі, відповідно, нижчий. ході господ рської діяльності відбув ється процес дегуміфік ції, він більше вир жений у верхній ч стині профілю. глибиною різниця у вмісті гумусу між грунт ми лісу й ріллі нівелюється. грунт х лісу процес зменшення вмісту гумусу з глибиною $є$ різкішим, ніж н ріллі. ході сільськогоспод рського використ ння відбув ється перемішув ння верхніх горизонтів сірих лісових грунтів ріллі, ун слідок чого вони ст ють гомогенними з м йже одн ковим вмістом гумусу.

ослідженнями з'ясов но, що в сірих лісових грунт $\mathrm{x}$ смового обужжя є 3 кономірність у вмісті гумусу з лежно від розміру грег тів. і зменшенням розміру грег тів вміст гумусу в них збільшується, оскільки вони повністю н сичені гумусом ун слідок гумосон копичення й кумуляції, тоді як в грег т х більшого розміру ктивн тільки поверхнев ч стин, що виявляється візу льно у вигляді н тіків н поверхні грег тів, з вищим вмістом гумусу, середня ч стин грег тів є більш інертною і менш гумусов ною.

\section{СПИСОК ВИКОРИСТАНОЇ ЛІТЕРАТУРИ}

1. $\phi$ н сьев . . ерноземы ереднерусской возвышенности / . . Ф н сьев .. : ук , 1966. $-224 \mathrm{c}$.

2. хтырцев . . генезисе серых лесных почв / . . хтырцев // очвоведение. 1979. - № 10. - . 24-33.

3. хтыриев . . ерые лесные почвы ентр льной оссии / . . хтырцев. - оронеж: зд-во оронеж. ун-т , 1979. - 233 с.

4. хтырцев . . зменение серых лесных почв реднерусской лесостепи в процессе сельскохозяйственного освоения / . . хтырцев, . . етинин . - p нск : зд-во ордов. ун-т , 1969. - 164 с.

5. еседин . . чественный сост в грег тов почв редней зии / . . еседин // p. сесоюз. хлопководств . - 1980. - № 10. - . 34-45.

6. огд нович . . міни у структурно- грег тному скл ді грунту при виведенні його 3 сільськогоспод рського використ ння / . . огд нович, . . домський // існик . рунтозн вство. - 2012. - № 3. - . 29-32.

7. ершинин . сновы грофизики / . . ершинин, . . ельников , . . ичурин и др. - . . : ос. изд-во физ.-м т. л-ры, 1959. - 903 с.

8. ильямс . . очвоведение / . . ильямс. - . : ельхзизд т, 1947. -238 с.

9. оронин . . труктурно-функцион льн я гидрофизик почв / . . оронин. . : ЗД-во оск. ун-т , 1984. - 204 с.

10. ерг чев . . рг ническое вещество почв: ст тик и дин мик (н примере п дной ибири) / . . ерг чев . - овосибирск : ук , 1984. - 190 с.

11. $p n$ чевский . . кологическое почвоведение / . . рп чевский. - . : , 2005. $-336 \mathrm{c}$.

12. ебедев . . овременные гумусовые ккумуляции в чернозем х усской р внины / . . ебедев // овременные проблемы почвоведения : учные труды очвенного ин-т им. . . окуч ев .- ., 2000. - . 55-67.

13. едведев . . труктур почвы / . . едведев. - рьков : 13 типогр фия, 2008. - 406 c. 
14. едведев . . р ктеристик водоудержив ющих сил и дифференци льной пористости м кро- и микро грег тов черноземных почв / . . едведев // Грохимия и почвоведение. -1969. - № 11. - . 85-92.

15. едведев . . льтр пористость и ктивн я поверхность м кро- и микро грег тов черноземных и темно-к шт новых почв / . . едведев // грохимия и почвоведение. - 1969. - № 10. - . 118-129.

16. рлов . . труктур почв светло-к шт нового комплекс в связи с х р ктером гумусовых веществ / . . рлов // ест. оск. ун-т . ер. 16. иол. и почвовед. 1959. - № 2. - . 75-84.

17. $\quad$ с сенко . . труктурно- грег тний скл д чорноземів типових лісостепу кр їни / . . н сенко // існик . - рунтозн вство. - 2012. - № 3. - . 49-53.

18. $і д в л ь н$. . умусовий ст н втоморфних грунтів смового обужжя : оногр фія / . . ідв льн , . . озняк. - ьвів : імені в н р нк, 2004. $192 \mathrm{c}$.

19. озняк . . рош емые черноземы юго-з п д кр ины / . озняк. - ьвов : , 1997. $-240 \mathrm{c}$

20. оном рев . . умус и почвообр зов ние / . . оном рев , . . лотников . - . : у ук , 1980. -220 с.

21. шевлоцький . . рунти ок льського п см і їх гротехногенн тр нсформ ція / . . шевлоцький, . . ськевич. - ьвів : імені в н р нк, 2002. $180 \mathrm{c}$.

22. убилин . . лияние сельскохозяйственного освоения н 3 п сы и сост в гумус серых лесных почв / . убилин, . олотов // очвоведение. - 1967. - № 6. . 3-9.

23. русевск я . . еогр фо-генетическ я особенность гумусного состояния серых лесных почв / . . русевск я, . . еш лкин , . . охлов // очвоведение. -2000 . - № 11. - . 1377-1390.

24. $\quad$ н . . рг но-минер льные соединения и структур почв / . . н. - . : ук , 1969. - $144 \mathrm{c}$.

25. ендев . . гротехногенное изменение темно-серых лесных почв ентр льной лесостепи з последние 200 лет / . ендев // очвоведение. - 1997. - № 1. $.10-21$.

26. киров . . тери лы к изучению к чественного сост в водопрочных грег тов почв в лесу / . . к киров, . . игм туллин, . . дредтинов // борник кр тких сообщ. з нск. ун-т. от ник, почвовед. - 1968. - № 1. . 140-146.

27. Grey C. L. Dependence of certain physical and chemical measurements in soil profile on the type of voter Stable aggregates / C. L. Grey, J. R. McHenry / Soil Sci. Soc. Am. Proc. - 1948. - Vol. 12. - P. 44-49.

28. Mazurak A. P. Physical and chemical properties of soil aggregates in a brunizem soil / A. P. Mazurak, H. D. Wittmus / Soil Sci. Soc. Am. Proc. - 1958. - Vol. 22. - P. 1-5.

\author{
m ття: н дійшл до ред кції 21.08.2012 \\ доопр иьов н 06.12 .2012 \\ прийнят до друку 20.02.2013
}




\title{
DISTRIBUTION OF HUMUS IN FRACTION OF STRUCTURAL UNITS OF GRAY FOREST SOIL OF RANGED POBUZHYA
}

\author{
Vitaliy Denys \\ Ivan Franko National University of Lviv, \\ P. Doroshenko St., 41, UA - 79000 Lviv, Ukraine
}

In this work presents the results of the research content of humus light gray and gray forest soils of Ranged Pobuzhya. We characterized the contents of humus in soils of different structural aggregates of agricultural use. Found that with decreasing size of the aggregates the humus content are increases and soil under forest characterized by the best indicators of humus content.

Key words: gray forest soils, light gray forest soil, humus, aggregates, structure.

\section{ит лий енис}

\author{
ввовский н цион льный университет имени в н рнко, \\ ул. . орошенко, 41, 79000, г. ьвов, кр ин
}

ро н лизиров но результ ты исследов ний содерж ния гумус светло-серых и серых лесных почв рядового обужья. х р ктеризов но содерж ние гумус в структурных грег т х почв р зличного сельскохозяйственного использов ния. ст новлено, что с уменьшением $\mathrm{p}$ змеp грег тов содерж ние гумус увеличив ется, почвы под лесом имеют лучшие пок 3 тели содерж ния гумус .

лючевые слов : серые лесные почвы, светло-серые лесные почвы, гумус, грег ты, структур . 